\title{
PERBEDAAN NYERI PADA PASIEN POST SECTIO CAESAREA SEBELUM DAN SESUDAH DILAKUKAN GUIDED IMAGERY
}

\author{
Ida Prijatni, Riza Umami, Malinda Capri NA \\ Poltekkes Kemenkes Malang, Prodi Kebidanan Jember \\ Jalan Srikoyo No. 106 Jember Jawa Timur \\ Email : ida.prijatni59@gmail.com

\section{The Difference of Pain in Patient of Post Sectio Caesarea Before and After Guided Imagery}

\begin{abstract}
Non pharmacological techniques to reduce pain after cesarean section surgery one of them with guided imagery which using someone's imagination designed specifically to achieve a certain positive effect. The purpose of this research is to know the difference of pain in patient of post sectio caesarea before and after done guided imagery. Design experimental research with cross sectional approach and one group pretest-posttest design. Sample 40 respondents, sampling using consecutive sampling. The research instrument using questionnaires and Guided imagery SOP, then data analyzed by Sample Paired T-Test. The results showed t arithmetic Sig. (2-tailed) $=0,000<0,05$ (á) which means $H O$ is rejected, in short there is a difference of pain in post-cesarean patients before and after guided imagery. It can be concluded that guided imagery can reduce pain especially in post-sectio caesarea patients.
\end{abstract}

Keywords: pain, post sectio caesarea, guided imagery

\begin{abstract}
Abstrak: Teknik non farmakologi untuk mengurangi nyeri setelah operasi sectio caesarea salah satunya dengan guided imagery yaitu menggunakan imajinasi seseorang yang dirancang secara khusus untuk mencapai efek positif tertentu. Tujuan dari penelitian ini adalah untuk mengetahui perbedaan nyeri pada pasien post sectio caesarea sebelum dan sesudah dilakukan guided imagery. Desain penelitian quasi experimental dengan pendekatan cross sectional dan rancangan one group pretest-posttest. Sampel 40 responden, sampling menggunakan consecutive sampling. Instrumen penelitian menggunakan kuisioner dan SOP guided imagery, kemudian data di analisa dengan uji Sample Paired T-Test. Hasil penelitian menunjukkan t hitung Sig. (2-tailed) $=0,000<0,05(\alpha)$ yang berarti Ho ditolak, sehingga ada perbedaan nyeri pada pasien post sectio caesarea sebelum dan sesudah dilakukan guided imagery. Dapat disimpulkan bahwa guided imagery dapat mengurangi rasa nyeri terutama pada pasien post sectio caesarea.
\end{abstract}

Kata Kunci: nyeri, post sectio caesarea, guided imagery

\section{PENDAHULUAN}

Sectio caesarea adalah suatu persalinan buatan, dimana janin dilahirkan melalui suatu insisi pada dinding perut dan dinding rahim dengan syarat rahim dalam keadaan utuh serta berat janin diatas 500 gram (Prawirohardjo, 2010). Indikasi sectio caesarea pada ibu dikarenakan panggul sempit/ CPD, Preeklampsia berat dan eklampsia, gagal induksi persalinan, plasenta previa, solusio plasenta, ruptura uteri, takut persalinan pervaginam, dan adanya keinginan untuk melahirkan pada hariyang telah ditentukan sedangkan pada janin dikarenakan terdapat kelainan letak, gawat janin, dan kehamilan ganda (Kosasih, 2015).

Pada umumnya setelah dilakukan sectio caesarea terdapat beberapa masalah seperti perdarahan, infeksi pada luka dan gangguan rasa nyaman (nyeri). Ketika ibu merasakan nyeri akan mengakibatkan beberapa gangguan seperti kualitas tidur menjadi buruk sebesar 85,7\% (Fitri dkk., 2012), mengurangi produksi ASI sebesar 
27,1\% (Nurliawati, 2010), dan malas untuk melakukan mobilisasi dini sehingga mengakibatkan proses penyembuhan luka menjadi lambat sebesar 45\% (Susanti, 2015).

Persalinan sectio caesarea di Indonesia tahun 2013 sebesar 9,8\% dan yang tertinggi berada di DKI Jakarta sebesar 19,9\%, sedangkan di Jawa Timur sebesar 12,2\% (Riskesdas, 2013). Jumlah persalinan sectio caesarea di Rumah Sakit Baladhika Husada Jember tahun 2015 sebanyak 814 kasus atau $81 \%$. Hasil penelitian yang dilakukan oleh Sucipto tahun 2012 di ruang nifas RSD dr. Soebandi Jember terdapat 30 responden yang mengalami nyeri. 14 responden mengalami nyeri ringan, 9 responden mengalami nyeri sedang, 5 responden mengalami nyeri berat, dan 3 responden mengalami nyeri sangat berat (Sucipto, 2012)

Nyeri merupakan kondisi berupa perasaan yang tidak menyenangkan. Sifatnya sangat subjektif karena perasaan nyeri pada setiap orang berbeda dalam hal skala atau tingkatannya, dan hanya orang tersebutlah yang dapat menjelaskan atau mengevaluasi rasa nyeri yang dialaminya (Ardhiyanti, 2014). Nyeri merupakan masalah yang sering ditemui pada pasien post sectio caesarea. Hal ini disebabkan oleh adanya peregangan otot uterus dan adanya insisional pada jaringan abdomen setelah efek anasetesi hilang. Nyeri yang dirasakan pasien post sectio caesarea tentulah bervariasi, mulai dari nyeri ringan sampai dengan nyeri berat sekali, bergantung pada faktor yang mempengaruhi nyeri karena sifat dari nyeri sangatlah subjektif, dampak dari nyeri jika tidak diatasi dengan baik akan mengakibatkan ibu mudah tersinggung, produksi ASI yang berkurang mengakibatkan puting ibu lecet karena hisapan bayi yang kuat, menyebabkan infeksi karena proses penyembuhan luka yang lambat, subinvolusi karena ibu tidak segera mobilisasi dini, dan pengeluaran lochea menjadi terhambat (Kosasih, 2015).
Upaya dalam mengurangi tingkat nyeri dapat dilakukan dengan dua cara yaitu farmakologis dan non-farmakologis. Cara non-farmakologis bisa dilakukan dengan cara akupunkutur, akupresur, massage, relaksasi benson, dan guided imagery. Guided imagery atau imajinasi terbimbing dapat mengurangi nyeri dengan menggunakan imajinasi seseorang yang dirancang secara khusus untuk mencapai efek positiftertentu (Muttaqin, 2008).

Guided imagery memiliki beberapa keunggulan daripada teknik relaksasi yang lain seperti membangkitkan kepercayaan diri dan optimis; meningkatkan relaksasi dan ketenangan dalam diri; menghilangkan siklus ketakutan, ketegangan, nyeri; meningkatkan endorfin alami; dan mengurangi keletihan (Walker, et al., 1999). Nyeri dapat diukur kembali setelah 5-10 menit sesudah dilakukan guided imagery. Keunggulan guided imagery juga diperkuat dengan adanya penelitian yang dilakukan oleh Sucipto (2012) yang menyatakan bahwa pasien post sectio caesarea mengalami penurunan nyeri sebesar 95\% setelah dilakukan guided imagery (Sucipto, 2012).

Tujuan penelitian ini untuk mengetahui perbedaan nyeri pada pasien post sectio caesarea sebelum dan sesudah dilakukan guided imagery. Tujuan khususnya adalah 1) mengukur skala nyeri pasien post sectio caesarea sebelum dilakukan guided imagery pada pasien, 2) mengukur skala nyeri pasien post sectio caesarea sesudah dilakukan guided imagery pada pasien, 3) menganalisis perbedaan skala nyeri pasien post sectio caesarea sebelum dan sesudah dilakukan guided imagery.

\section{METODE PENELITIAN}

Penelitian ini merupakan penelitian quasi eksperimental. Pendekatan penelitian ini menggunakan cross sectional dan menggunakan rancangan one group pretest-posttest. 
Populasi pada penelitian ini adalah semua pasien post sectio caesarea dari tanggal $6 \mathrm{Mei}-$ 6 Juni 2017 dengan jumlah 40 pasien. Sampel dalam penelitian ini adalah total populasi ibu post sectio caesareaprimipara dari tanggal 6 Mei-6 Juni 2017 dengan jumlah 40 pasien. Teknik sampling menggunakan consecutive sampling

Kriteria inklusi dalampenelitian ini: 1) pasien mengeluh nyeri, 2) pasien primigravida, 3) bersedia menjadi responden. Kriteria eksklusinya : pasien tidak kooperatif dan menolak menjadi responden.

Variabel penelitian, variabel dependen yang pertama adalah tingkat nyeri pasien dengan nyeri post sectio caesara sebelum diberi teknik guided imagery dan variabel dependen yang kedua adalah tingkat nyeri pasien dengan nyeri post sectio caesarea sesudah diberi teknik guided imagery.

\section{HASIL PENELITIAN}

Karakteristik responden berdasarkan usia didapatkan sebagian besar responden berusia 17-25 tahun yaitu 27 responden $(67,5 \%)$ dan 23 responden $(32,5 \%)$ berusia $26-35$ tahun.
Berdasarkan pendidikan diketahui bahwa sebagian besar responden berpendidikan SMA sebanyak 24 orang $(60 \%)$, SMP sebanyak 7 orang $(17,5 \%)$, dan Perguruan Tinggi sebanyak 9 orang $(22,5 \%)$.

Tabel 1 menunjukkan bahwa nyeri sebelum dilakukan guided imagery sebagian besar berada pada skala nyeri 6 sebanyak 10 responden (25\%). Selanjutnya, setelah dilakukan guided imagery sebagian besar mengalami penurunan nyeri dan berada pada skala nyeri 2 sebanyak 8 responden $(20 \%)$.

\section{PEMBAHASAN}

Hasil penelitian yang dilakukan pada 40 responden post sectio caesarea menunjukkan bahwa sebagian besar nyeri responden berada pada skala nyeri 6 sebanyak 10 responden sebelum guided imagery. Menurut Guyton dan Hall dalam Kosasih (2015) menyatakan bahwa hampir semua jaringan tubuh terdapat ujung-ujung saraf nyeri. Ujung-ujung saraf ini merupakan ujung saraf yang bebas dan reseptornya adalah nociceptor. Pada ibu post sectio caesarea akan mengalami nyeri. Hal ini dikarenakan adanya insisi

Tabel 1. Perbedaan Nyeri Pada Pasien Post Sectio Caesarea Sebelum dan Sesudah Dilakukan Guided Imagery

\begin{tabular}{ccccc}
\hline \multirow{2}{*}{ Skala Nyeri } & \multicolumn{2}{c}{ Sebelum } & \multicolumn{2}{c}{ Sesudah } \\
\cline { 2 - 5 } & F & \% & F & \% \\
\hline 1 & - & - & 7 & 17,5 \\
2 & 1 & 2,5 & 8 & 20 \\
3 & 3 & 7,5 & 7 & 17,5 \\
4 & 1 & 2,5 & 5 & 12,5 \\
5 & 9 & 22,5 & 5 & 12,5 \\
6 & 10 & 25 & 3 & 7,5 \\
7 & 7 & 17,5 & 4 & 10 \\
8 & 4 & 10 & 1 & 2,5 \\
9 & 5 & 12,5 & - & - \\
\hline Jumlah & 40 & 100 & 40 & 100 \\
\hline
\end{tabular}


pada uterus sehingga terjadi kerusakan jaringan (Kosasih, 2015). Syaraf penghantar nyeri tersebut timbul pada T11-T12 yang berhubungan dengan medulla spinalis (Thompson, 2016). Hal ini dapat merangsang munculnya histamin, bradikanin, kalium dan substansi $\mathrm{P}$ yang diproduksi oleh tubuh. Zat-zat kimia ini akan menimbulkan rasa nyeri. Selanjutnya, impuls nyeri ini dibawa oleh serabut saraf deltaA dan serabut sarafC menuju medula spinalis. Serabut delta A bersifat cepat, diselubungi oleh myelin, sangat kecil dan mengirimkan sensasi yang tajam, terlokalisasi dan jelas/nyata. Serabut $C$ bersifat lambat, tidak diselubungi myelin dan menghantarkan impuls nyeri terbakar/sangat panas dan menetap. Dalam beberapa detik, rasa nyeri mulai menyebar dan meluas, sehingga terasa sakit di area bekas insisi dikarenakan adanya suplai dari serabut C (Potter \& Perry, 2009). Di medula spinalis, talamus menstransmisikan informasi ke pusat yang lebih tinggi di otak. Ketika stimulus nyeri sampai di korteks serebral, maka otak akan menginterpretasikan kualitas nyeri dan persepsi nyeri (Potter \& Perry, 2009).

Tindakan post sectio caesarea meninggalkan bekas sayatan di kulit abdomen dan mengakibatkan terputusnya jaringan pada bagian yang di insisi. Adanya hal tersebut mengakibatkan timbulnya zat-zat kimia berupa histamin, bradikinin, kalium dan substansi P. Zatzat kimia ini dibawa oleh serabut saraf delta $\mathrm{A}$ dan $C$ yang berperan membawa transmisi nyeri dari medula spinalis menuju talamus. Selanjutnya transmisi nyeri dilanjutkan menuju korteks serebal dan otak akan mempersepsikan nyeri. Hal inilah yang mengakibatkan responden merasakan nyeri pada daerah insisi setelah efek anastesi hilang. Responden post sectio caesarea akan mengalami rasa nyeri yang digambarkan dalam skala nyeri.

Hasil penelitan diruang Dahlia RS Baladhika Husada Jember menunjukkan setelah dilakukan guided imagery pada 40 responden, sebagian besar mengalami penurunan nyeri dan berada pada skala nyeri 2 sebanyak 8 responden $(20 \%)$. Nyeri merupakan kondisi berupa perasaan yang tidak menyenangkan. Sifatnya sangat subjektif karena perasaan nyeri pada setiap orang berbeda dalam hal skala atau tingkatannya, dan hanya orang tersebutlah yang dapat menjelaskan atau mengevaluasi rasa nyeriyang dialaminya. Guided imagery merupakan salah satu teknik untuk menguranginyeri. Berawal dari suara terapis yang masuk dari daun telinga (pinna) pasien dibawa oleh gelombang menuju ke ganglion spiralis corti pada bagian ini terdapat Nervus koklearis adalah saraf sebenarnya yang berada di nervus auditorius. Akson dibawa menuju ke korteks auditorius yang berada di lobus temporalis. Lobus temporalis berada di bagian tepi otak dan di atas telinga serta di belakang pelipis. Lobus ini terlibat dalam ingatan dan emosi serta mengandung korteks auditorius yang bertugas untuk memproses suara. Bagian kiri dari lobus temporalis disebut dengan area Wenickle (Wade \& Carol T, 2015). Area ini berkaitan dengan talamus dan berperan mengubah suara menjadi bahasa yang dimengerti otak (Guyton \& Hall, 1997). Bahasa tersebut mengaktifkan hipotalamus untuk merangsang kelenjar hipofise anterior guna mensekresikan hormon endorfin. Alur saraf descenden melepaskan opiat endogen seperti endorfin yang merupakan suatu zat alami yang berasal dari tubuh. Melalui saraf descenden yang keluar dari otak, endorfin ditransmisikan oleh saraf-saraf sensori $\beta$ A. Ketika endorfin berikatan dengan reseptor opiate yang berada di kornu dorsalis medulla spinalis, maka akan menghambat pelepasan substansi P. Karena substansi P dihambat, maka impuls nyeri tidak sampai ke korteks serebri dan pasien tidak mempersepsikan nyeri (Guyton \& Hall, 1997).

Cara kerja guided imagery yaitu mengajak responden membayangkan hal yang disenangi seperti membayangkan pemandangan indah sehingga membuat responden menjadi rileks. 
Suara terapis yang membimbing responden untuk membayangkan hal yang indah dan menyenangkan masuk ke dalam telinga menuju ganglion spiralis corti. Selanjutnya, akan diteruskan ke korteks auditorius oleh nervus koklearis dan diproses di lobus temporalis tepatnya pada area Wenickle. Hasil dari proses tersebut berupa bahasa yang dimengerti otak. Hipotalamus akan mengaktifkan kelenjar hipofise anterior untuk menghasilkan hormon endorfin. Saat responden berhasil membayangkan hal yang menyenangkan, maka saat itulah hormon endorfin bekerja. Dikarenakan adanya endorfin yang mengikat substansi P inilah, maka nyeri diblok dan tidak bisa dipersepsikan oleh responden. Responden akan menjadi rileks. Hal inilah yang menjadikan responden dari tingkat nyeri sedang menurun menjadi nyeri ringan.

Berdasarkan hasil dari proses penghitungan uji statistik paired sample t-test, didapatkan hasil terdapat perbedaan nyeri pada pasien post sectio caesarea sebelum dan sesudah dilakukan guided imagery. Hasil penelitan di ruang Dahlia RS Baladhika Husada Jember menunjukkan bahwa sebanyak 40 responden mengalami penurunan nyeri. Sebelum dilakukan guided imagery sebanyak 10 responden (25\%) berada pada skala nyeri 6 dan setelah dilakukan guided imagery sebanyak 8 responden (20\%) mengalami penurunan nyeri pada skala nyeri 2 . Nyeri pada pasien post sectio caesarea dikarenakan ada kerusakan pada jaringan akibat adanya kontinuitas jaringan yang terputus. Kemudian timbul histamin, bradikanin, kalium dan substansi $\mathrm{P}$ yang diproduksi oleh tubuh. Zat-zat kimia ini akan menimbulkan rasa nyeri. Rasa nyeri ini ditransmisikan pada serabut tipe $\mathrm{C}$ yang menghasilkan sensasi seperti terbakar atau pada serabut Tipe A yang menghasilkan nyeri, seperti tertusuk (Kosasih, 2015). Adanya nyeri dapat dikurangi dengan menggunakan guided imagery. Waktu yang dibutuhkan untuk teknik guided imagery yaitu 15-20 menit (Gottlieb, 1995).
Guided imagery merupakan salah satu strateginon-farmakologiuntuk mengurangi nyeri dimana pasien diajak untuk membayangkan hal yang menyenangkan. Pada penelitian berlangsung selama 30 hari dan masing-masing responden diteliti selama \pm 40 menit serta ibu post sectio caesarea adalah salah satu subyek penelitian yang sesuai untuk terlibat dalampenelitian ini. Prosedur pengambilan bahan penelitian/ data menggunakan SOP dan mengisi lembar kuisioner, yang membutuhkan waktu sekitar \pm 5 menit dan dilanjutkan dengan melakukan guided imagery selama 15-20 menit.

Hasil dari uji statistik menunjukkan $\mathrm{Ha}$ diterima sehingga terdapat perbedaan nyeri pada pasien post sectio caesarea sebelum dan sesudah dilakukan guided imagery.

\section{PENUTUP}

Kesimpulan dari penelitian antara lain: 1) nyeri sebelum dilakukan guided imagery yang mengalami nyeri terbanyak pada skala 6 (25\%), 2) nyeri sesudah dilakukan guided imagery mengalami nyeri terbanyak pada skala $2(20 \%)$, 3 ) ada perbedaan nyeri pada pasien post sectio caesarea sebelum dan sesudah dilakukan guided imagery.

Hasil penelitian ini dapat dijadikan sebagai penatalaksanaan non-farmakologi untuk mengatasi nyeri pada pasien post sectio caesarea.

Peneliti selanjutnya dapat melakukan penelitian dengan judul yang sama, akan tetapi respondennya bisa dirubah menggunakan ibu primipara dan multipara serta uji statistiknya bisa menggunakan uji wilcoxon.

\section{DAFTAR PUSTAKA}

Ardhiyanti, Y. (2014). Panduan Lengkap Keterampilan Dasar Kebidanan 1 1st ed., Yogyakarta: Deepublish. 
Fitri, M., Trisyani, M., Maryati, I. (2012). Hubungan Intensitas Nyeri Luka Section Caesarea dengan Kualitas Tidur pada Pasien Postpartum Hari ke-2 di Ruang Inap RSUD Sumedang. Students e-Journal, 1(1), 34.

Gottlieb, B. (Ed.). (1995). New choices in natural healing: Over 1,800 of the best selfhelp remedies from the world of alternative medicine. Rodale.

Guyton, A. C., \& Hall, J. E. (1997). Buku Ajar Fisiologi Kedokteran. (I. Setiawan, Ed.) (9th ed.). Jakarta: EGC.

Muttaqin, A. (2008). Buku Ajar Asuhan Keperawatan Klien dengan Gangguan Sistem Persarafan. Jakarta: Salemba Medika.

Nurliawati, E. (2010). Faktor-faktor yang Berhubungan dengan ProduksiAir Susu Ibu Pada Ibu Pasca Seksio Sesarea di Wilayah Kota dan Kabupaten Tasikmalaya. Jurnal FIK UI

Potter, P.A. \& Perry, A.G. (2009). Fundamental Keperawatan, Edisi 7 Buku 3 7th ed. D. N. Fitriani, O. Tampubolon, \& F. Diba, eds., Jakarta: Salemba Medika.

Prawirohardjo, S. (2010). Ilmu Bedah Kebidanan 1st ed. H. Wiknjosastro, ed., Jakarta: PT. Bina Pustaka Sarwono Prawirohardjo.
Riskesdas. (2013). Riset Kesehatan Dasar 2013, Jakarta: Badan Penelitian dan Pengembangan Kemenkes RI

Kosasih, C.E. (2015). Konsep dan Aplikasi Relaksasi dalam Keperawatan Maternitas. Bandung: PT Refika Aditama.

Sucipto, A.Y. (2012). Pengaruh Relaksasi Guided Imagery Terhadap Tingkat Nyeri Pasien Pasca Operasi Sectio Caesarea di Rumah Sakit Daerah dr. Soebandi Jember. Skripsi. Jember: Universitas Negeri Jember

Susanti, I.Y. (2015). Mobilisasi Dini Terhadap Penyembuhan Luka Paska Seksio Sesaria di RSU Wahidin Sudiro Husodo Kota Mojokerto. Jurnal Keperawatan Sehat, 12 (02)

Thompson, L. (2016). Teach Me Anatomy. http://teachmeanatomy.info/pelvis/female-reproductive-tract/uterus/.

Wade \& Carol T. (2015). Psikologi Jilid 19 th ed., Jakarta: Erlangga.

Walker, L. G., Walker, M. B., Ogston, K., Heys, S. D., Ah-See, A. K., Miller, I. D., ... \& Eremin, O. (1999). Psychological, clinical and pathological effects of relaxation training and guided imagery during primary chemotherapy. British journal of cancer, $80(1-$ 2), 262. 